\title{
ARIZONA TEWA KIVA SPEECH AS A MANIFESTATION OF LINGUISTIC IDEOLOGY ${ }^{1}$
}

\author{
Paul V. Kroskrity
}

\section{Introduction}

"What have you learned about the ceremonies?" Back in the Summer of 1973, when I first began research on Arizona Tewa, I was often asked such questions by a variety of villagers. I found this strange, even disconcerting, since the questions persisted after I explained my research interest as residing in the language "itself", or in "just the language, not the culture". My academic advisors and a scholarly tradition encouraged me to attribute this response to a combination of secrecy and suspicion regarding such culturally sensitive topics as ceremonial language. Yet despite my careful attempts to disclaim any research interest in kiva speech (te'e hi:li) and to carefully distinguish between it and the more mundane speech of everyday Arizona Tewa life, I still experienced these periodic questionings. Did these questions betray a native confusion of the language of the kiva with that of the home and plaza? Was there a connection between these forms of discourse that was apparent to most Tewa villagers yet hidden from me? In the past few years, after almost two decades of undertaking various studies of Arizona Tewa grammar, sociolinguistic variation, language contact, traditional narratives, code-switching, and chanted announcements, an underlying pattern of language use has gradually emerged which, via the documentary method of interpretation has allowed me to attribute a new meaning to these early interrogations. ${ }^{2}$ The disparate linguistic and discourse practices, I contend, display a common pattern of influence from te'e hi:li "kiva speech". The more explicit rules for language use in ritual performance provide local models for the generation and evaluation of more mundane speech forms and verbal practices.

\footnotetext{
${ }^{1}$ Acknowledgements. I would like to thank Kathryn Woolard for her comments on an earlier version of this article which was presented as part of the 1991 American Anthropological Association symposium, "Language Ideologies: Practice and Theory". In addition, I would like to thank the other coorganizers of that original symposium, Bambi Schieffelin and Kathryn Woolard, as well as our many distinguished participants.

2 By "documentary method of interpretation" I mean the ethnomethodological process which provides that retrospective clarity and revised interpretation in the construction of both commonsense and expert knowledge (Garfinkel 1967: 77ff.).
} 
evaluation of more mundane speech forms and verbal practices.

"Linguistic ideologies", taken in Michael Silverstein's (1979) sense as "... sets of beliefs about language articulated by users as a rationalization or justification of perceived language structure and use," provide a useful frame for understanding the Arizona Tewa pattern. By viewing member's reflectivity, or what Giddens (1984) calls "reflexive monitoring," as an irreducible force in language behavior, the notion of linguistic ideology directs attention to cultural actors' rationalization of their own language activity. As Silverstein (1985: 220) writes:

"The total linguistic fact, the datum for a science of language, is irreducibly dialectic in nature. It is an unstable mutual interaction of meaningful sign forms contextualized to situations of interested human use mediated by the fact of cultural ideology."

Examining the Arizona Tewa culture of language as a site for the investigation of linguistic ideologies is multiply warranted. As a Pueblo Indian group which removed itself from Spanish influence in 1700 by migrating to the easternmost of the Hopi mesas and, since then, maintained its indigenous Kiowa-Tanoan language, the Arizona Tewa are "twice-blessed" with a cultural self-consciousness about language use. First, as Pueblo Indians, they are paragons of what Joel Sherzer (1976) and others have termed "linguistic conservatism" - that celebrated penchant for resistance to linguistic borrowing. But whatever analytical value this concept may have to students of language contact, it has at best only the most tentative footing in terms of its foundations in Arizona Tewa cultural experience. Examination of Arizona Tewa linguistic ideology, I contend, offers an alternative, culturally based interpretation - a deconstruction of "linguistic conservatism" into dimensions that are simultaneously more analytically precise and more locally rooted.

A second source of Arizona Tewa cultural emphasis on language is their own remarkable history of language contact and language maintenance. In the diaspora of the Pueblo Revolts of 1680 and 1696 , the Arizona Tewa are the only outmigrating group that retained its language into the present ${ }^{3}$. Maintenance of the Tewa language served not only to perpetuate an ethnic boundary but also to mask a pattern of dramatic cultural change in adapting to the Hopi - the group to whom the ancestors of the Arizona Tewa migrated almost three hundred years ago. This adaptation was quite necessary for physical survival in the harsh western Pueblo environment. The Arizona Tewa saying Na:-bi hi:li na:-bi wowa:ci na-mu "My language is my life (history)" reveals the intimate relationship between language, history, and identity which this migration has fostered as well as the cultural salience of the connection. Thus the culture-specific history of the Arizona Tewa has enhanced a Pan-puebloan attention to language which may account for its magnified local significance.

3. For a more complete discussion of the Pueblo diaspora, interested readers should consult Simmons (1979) and Schroeder (1979). 


\section{Local Knowledge and Linguistic Ideology}

Though the role of native language maintenance in response to their Hopi hosts is somewhat peculiar to the Arizona Tewa, the cultural prominence of kiva speech - the speech performed in religious chambers when sacred ceremonial altars are erected is common to all Pueblo societies. As a key symbol of Tewa linguistic values, kiva talk embodies four closely related cultural preferences: regulation by convention, indigenous purism, strict compartmentalization, and linguistic indexing of identity. For each of these I would like to briefly sketch: 1) their basis in kiva talk, 2) their cultural salience as manifested in members' recognition, and 3) the "scope" and "force" with which these preferences are manifested in non-ritual speech. By "cultural salience", I mean approximate location on a scale of awareness ranging from practical consciousness/tacit knowledge, on the one hand, to discursive consciousness/explicit knowledge on the other (Giddens 1984). In using "scope" and "force" I follow Geertz's (1968) study of Islamic belief in which he used the former to refer to the range of contexts in which some value or belief would be manifested and the later to characterize its intensity.

\subsection{Regulation by convention}

In the kiva, ritual performers rely on fixed prayer and song texts. Innovation is neither desired nor tolerated. Proper ritual performance should replicate past conventions and if such repetition is impossible the ritual should not be performed at all. Thus in instances where the ceremonial knowledge has not been effectively transmitted from one priest to his apprentice, the ceremony becomes defunct. This concern with regulation by convention is manifested in everyday speech preferences by adherence to greeting formulae, to the extended use of kinship terms in address forms, to rules of hospitality involving kinsmen and visitors, and to avoidance of direct confrontation in interaction with fellow villagers. Culturally valued native genres, involving either histories or traditional stories, must carefully conform to the traditional formal precedents associated with those genres.

In traditional stories, for example, from the Arizona Tewa genre $p e ̨: y u ' u$, audience members and performers alike honor a tradition which employs stylized non-verbal accompaniment and uses familiar storytelling conventions. Foremost among these ways of "speaking the past" is the use of evidential ba as a genre marker (Kroskrity 1985). By disclaiming any novelty on the part of the narrator, this particle and its repeated use provide a continurous and obligatory indexing of "the voice" of the traditional narrator. Example 1, the introductory sentence of the story "Coyote and Bullsnake" exemplifies a pattern of multiple occurence within each sentence uttered in the voice of the narrator (as opposed to story characters' voices or frame- breaking asides in a personal voice).

$$
\begin{array}{ll}
\begin{array}{l}
\text { ową́eheyám-ba } \\
\text { bayaena-senó ba }
\end{array} & \text { long:ago ba } \\
\text { Old Man Coyote ba }
\end{array}
$$

Long ago, so they say

Old Man Coyote so 
na-tha. ${ }^{4}$

he lived.

he lived.

Thus a particle which denotes the second-hand nature and traditional character of what is said - similar to our "so they say" - aptly functions as a discourse marker of a genre of traditional stories.

Even when narrators chose to speak the present - to contextualize their stories for specific audiences, such innovations should ideally occur in the voice of the narrator (e.g. through episode editing and elaboration, nonverbal audience specification, the addition of identifying details that might be "tied" to specific audience members). Narrators who chose such frame-breaking strategies as code-switching and the introduction of a personal voice (unmarked by ba) or who merely forgot to clearly delineate the "voice of the traditional narrator" by excluding $b a$ were negatively evaluated for their efforts by audience members who criticized them for not telling it "right," not telling it the "old way".

If innovation, even in the form of contextualization, is to be culturally sanctioned it must be cloaked in traditional garb. I encountered an interesting and creative use of traditional linguistic form one summer when I heard what sounded like a traditional

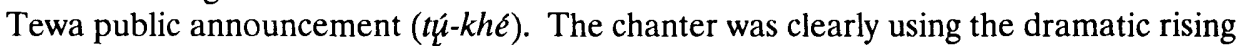
and falling intonations asssociated with the "public address" style reserved for crier chiefs to announce upcoming ceremonies or call for volunteers for village projects like cleaning out a spring, replastering the kiva, or for individuals to offer birth announcements or stylized grievance chants (Black 1967). But while the form was traditional, its content and presenter were not. The chanter was issuing a call for a yard sale and inviting all within earshot to examine items of used clothing and some small appliances which she hoped to sell! An example of this is provided in example 2.

(2) kwiyó:, he:wae khe: 'i-kw'ón wí-t'olo-kánt'ó
women some clothes they-lie I/you-tell-will

Women: I'm telling you there are some clothes lying.

náe' áe phíní-bí-k'ege 'i:-kư-kwín-áe’ae-mí

here Phini-'s-house you:all-buy-look-come-should

You all should come and shop at Phini's house.

$\begin{array}{lll}\text { kínán } & \text { dí-túc-án-dán } & \text { wí-t'olo-’án } \\ \text { this } & \text { I/other-say-since } & \text { I/you-tell-past }\end{array}$

\footnotetext{
${ }^{4}$ For ease of presentation to a diverse audience, I have opted to use an orthography which departs from conventional Americanist practices in at least two respects. I have eliminated superscript indications of secondary articulation (e.g. aspiration, palatalization) and instead represented these with digraphs. Also the apparent vowel cluster, ae, is simply a low. mid front vowel.
} 
This is what I was told to tell you.

Though the "commercial" message was hardly traditional, the chanter won general village approval by conforming to the expected intonational and other prosodic patterns as well as the verbal formulae associated with the genre. Despite the brevity of this "short notice" announcement, its obedience to such generic norms as initial addresse specification, explicit acknowledgement of the announcer role, as well as its prosodic fidelity to traditional models, prompted all but the most ultraconservative villagers to overlook the fact that the chanter was a woman..$^{5}$ Importantly both the gender of chanter as well as its commercial content - both violations in a genre normally performed by men announcing communal activities - were subordinated in public opinion to an approval of its traditional form.

\section{2-3. Indigenous purism and strict compartmentalization}

Indigenous purism and strict compartmentalization are two dimensions of Arizona Tewa linguistic ideology which, though analytically distinguishable are intimately joined in most linguistic practices. During ritual performance there is an explicit and enforced proscription against the use of foreign words and/or native vocabulary clearly identified with an equally alien social dialect (such as slang=recently manufactured words lacking any association to prestigous individuals or activities (e.g. Newman 1955). As for enforcement, Frank Hamilton Cushing's experience is exemplary. For uttering a Spanish word in a Zuni kiva he was struck forcefully across the arms by a whipper kachina. After being so purified, he was instructed to say the Zuni equivalent of "Thank you." Stanley Newman (1955: 349) in his discussion of vocabulary levels of the Zuni appears to dismiss purism in passages such as the following:

Likewise obviously borrowed words, such as melika "Anglo-American" cannot be used in the kiva. This prohibitiion against loanwords is obviously not to be equated with traditions of linguistic purism, whereby organizations in many modern national states legislate against foreignisms that threaten to adulterate the native language. It stems rather from the general Zuni injunction against bringing unregulated innovation into ceremonial situations. Using a word like melika, as one informant expressed it, would be like bringing a radio into the kiva.

Though Stanley Newman has discouraged the interpretation of such kiva practices as strictly analogous to enforced policies of language purism in contemporary nation-states, the kind of purism that Newman is dismissing amounts to an official proscription of linguistic diffusion (e.g. loanwords, grammatical interference) not only in ceremonial speech but in everyday speech as well. But Tewa ceremonial leaders like those of other pueblos are not waging a campaign to dictate everyday speech norms. Any purging of foreignisms in everyday speech represents a popular extrapolation - a symbolic "trickle down" influence of the salient and prestigous model of kiva speech.

\footnotetext{
${ }^{5}$ Announcements display varying degrees of elaboration depending upon whether they are seen as "utvance" or "short" notice. The latter are often viewed as reminders and do not contain the full details.
} 
The primary concern of ceremonial leaders is with maintaining and delimiting a distinctive and appropriate linguistic variety, or vocabulary level, for religious expression and not primarily with minimizing foreign linguistic influence. The strong sanctions against foreign expressions in ceremonial speech, sanctions which involve physical punishment, are motivated not by the linguistic expression of xenophobia or extreme ethnocentrism but by the need for stylistic consistency in a highly conventionalized liturgical speech level. Similarly the negative evaluation of instances of code-mixing in everyday speech by members of the Arizona Tewa speech community does not reflect negative attitudes about these other languages but rather the functioning of ceremonial speech as a local model of linguistic prestige.

This role should not be too surprising when we observe that the prestige which accrues to "standard languages" in modern nation-states emanates, in part, from the support of and use by national governments and by their association with formal education. Since Pueblo societies are traditionally theocratic, fusing political power and religious authority, and since ceremonial leaders must acquire appropriate knowledge through rigorous verbal instruction, the functional role and cultural associations of ceremonial speech are actually quite analogous to standard languages.

Further supporting this claim that the negative evaluation of code-mixing, especially prevalent in older speakers (Kroskrity 1978), is attributable more to local models than to xenophobia are two types of telling observations. One, speakers regulate language mixing from languages which they highly value and use proficiently. Certainly, the Arizona Tewa - as I have argued elsewhere (Kroskrity, in press) - have many social identities which are performed in the non-ethnic languages of their linguistic repertoire: Hopi and English. Hopi is an essential medium of intervillage communication and the appropiate language for relating to Hopi kinsmen. Command of English has permitted the Arizona Tewa to gain significant economic and political advantages over the Hopi in their role as cultural brokers, mediating between Euro-Americans and the more conservative Hopi. Fluency in these languages is necessary for full participation in Arizona Tewa society. Though fluency in these languages is never criticised by the Tewa, language mixing between these languages is routinely and consistently devalued. Another type of evidence which argues against viewing this devaluation of language mixing as an expression of xenophobia is the well established tradition of song-borrowing from other linguistic traditions (Charlotte Heth and Paul Humphreys, personal communication). Entire songs, solely encoded in foreign languages, are often performed in Tewa Village and throughout the Pueblos. It is difficult to explain the popularity of this tradition if one wants to argue for a xenophobic interpretation of ideal speech norms against code- switching.

Though the Arizona Tewa clearly lack the deliberation and institutional enforcement often associated with "purist" movements, Arizona Tewa indigenous purism may not lack other atributes that language planning theorists associate with linguistic purism. Scholars such as Jernudd (1989: 4), for example, view such movements in modern nation states as consisting of a bidirectional process involving the simultaneous opening of native resources and the closing off of non-native ones for linguistic change. Manfred Henningsen (1989: 31-2) expands on the latter aspect when 
he says, "the politics of purity ... originates in a quest for identity and authenticity of a cultural Self that feels threatened by the hegemonic pressure of another culture." Annamalai (1989: 225), too, also observes that purism is "manifest when there is social change affecting the structure of social control." But while resistance to hegemony and rapid sociocultural change may be the prerequisite of linguistic purism in modern nation states, these conditions havealso prevailed for the Arizona Tewa and their Southern Tewa ancestors since the time of Spanish contact in the sixteenth century. From the repressive colonial program of the Spanish, to post-migration Hopi stigmatization and segregation, to "domestic" colonization by the United States, it is certainly possible to find a consistent pattern of Tewa resistance to hegemonic pressure. But it would be wrong to assume that purism is coincident with such hegemony. Data from contact with Apachean languages tracable to the late pre-Spanish contact period, shows the same pattern of loanword suppression (Kroskrity 1982, 1985b) and strongly suggests that the practice of indigenous purism was already in place. What has been even more continuous than hegemonic pressure from outside is the prestigious position of the traditional religious leaders - an "internal" hegemonic force - and the speech norms associated with them.

But if Arizona Tewa indigenous purism lacks a social organization dedicated to its systematic enforcement, the Arizona Tewa people themselves are usually quite explicit about its value. In Albert Yava's approximation of a life history known as Big Falling Snow he proudly compares the Arizona Tewa to the Rio Grande Tewa (Yava 1978: 1)

"We still speak the Tewa language and we speak it in a more pure form than the Rio Grande Tewas do. Over there in New Mexico the Tewa language has been corrupted by other Pueblo languages and Spanish. We also speak Hopi fluently though there are very few Hopis who can converse in Tewa."

The third value, strict compartmentalization, is also of great importance to the understanding of Arizona Tewa linguistic ideology. Essential to kiva talk is the maintenace of a distinctive linguistic variety which is dedicated to a well demarcated arena of use. "Kiva talk" would lose its integrity if it admitted expressions from other languages or from other linguistic levels. Likewise, if "kiva talk" were to be spoken outside of ceremonial contexts it would profane this liturgical variety and constitute a flagrant violation. This strict compartmentalization of language forms and use has often been recognized as a conspciuous aspect of the language attitudes of Pueblo cultures (Dozier 1956; Sherzer 1976: 244). What is novel here is the recognition that this value, like regulation by convention and indigenous purism is tracable to the adoption of kiva talk as the local model of linguistic prestige. Just as ceremonial practitioners can neither mix linguistic codes nor use them outside of their circumscribed contexts of use, so - ideally speaking - Tewa people should observe comparable compartmentalization of their various languages and linguistic levels in their everyday speech.

The mixing of Tewa with either English or Hopi is explicitly devalued by members of the Tewa speech community though in unguarded speech some mixing does occur. It is interesting that in the Tewa folk account of speech variation social categories are ranked in respect to the perceived avoidance of language mixing. Older 
speakers, for example, are said to approximate this ideal more than younger. Men do so more than women. It should be emphasized that this folk perception can be readily interpreted as a reflection of the different participation of these groups in ceremonial activities, of their differential proximity to the realm of "kiva talk".

Examining both historical linguistic data and more contemporary sociolinguistic studies of the Arizona Tewa confirms the selective influence of indigenous purism and strict compartmentalization. Though time does not permit me to reproduce all the relevant genetic-historical and areal-historical comparisons which permit these conclusions, it is important to summarize a pattern of linguistic ideology shaping the form of linguistic diffusion in three periods of language contact. The pattern features the suppression of linguistic borrowing, especially in the lexicon. In multilingual episodes with Apacheans, the Spanish, and the Hopi lasting 100, 150, and 191 years respectively, the Arizona Tewa language has admitted two Apachean, 17 Spanish, and one Hopi loanword (Kroskrity 1982, in press). Clearly Arizona Tewa folk linguists have put into practice the indigenous purist and strict compartmentalization planks of Arizona Tewa linguistic ideology. But there is also clear evidence that folk attention is selective. The approximation of these ideals in actual practice presupposes a folk perception of "alien" linguistic structures and yet Arizona Tewa linguists, unlike our own, are primarily if not exclusively lexicographers. Abundant evidence suggests that several grammatical structures in Arizona Tewa are the result of linguistic convergence. Thus, as illustrated in example 3 , the innovation of a Possessive or relational suffix in Tewa appears to be the result of contact with Apachean languages.

$\begin{array}{cl}\text { TEWA } & \text { sen-bí 'é:nu } \\ & \text { man-'s son } \\ & \text { (a man's son } \\ & \text { 'é:nu-bí nứcú } \\ \text { boy-'s under } \\ \text { under the boy }\end{array}$

NAVAJO

hastiin bi-ye' man 's ${ }^{6}$-song

(a) man's son

hastiin bi-ch'ạáh

man 's-front

in front of the man

These two phrases, in both Arizona Tewa and Navajo, demonstrate both the phonological and grammatical similarity of the affixes. In both languages, these constituents are used in possessive constructions and with locative postpositions. Significantly, no other Kiowa-Tanoan language has this constituent. This strongly suggests grammatical diffusion from Apachean languages as the source for Arizona Tewa -bí.

Similarly Arizona Tewa has innovated a new Passive suffix which now alternates with an inherited one shared by Rio Grande Tewa. Example (4) illustrates the parallel Arizona Tewa and Hopi constructions.

${ }^{6}$ Though Apachean bi- is the source for Tewa $\underline{-b i}$, Tewa has overgeneralized it as a general possessive morpheme whereas in the Apachean languages it is limited to third person. 
(4) TEWA p’o na-kulu-tí

water it-pour-PAS

The water was poured.
HOPI taawi yuk-ilti

song finish-PAS

The song was finished.

(Kalectaca 1978:132)

Though Arizona Tewa has a passive suffix, $-\boldsymbol{n}$, which it shares with Rio Grande Tewa, the $-t$ suffix represents a grammatical borrowing from analogous Hopi structures. Again, in an instance of ongoing linguistic change emerging from sociolinguistic variation, younger Arizona Tewa speakers now only produce one of the three structural alternatives for realizing phrasal conjunction that are available for the oldest generation of speakers (Kroskrity 1982). Significantly it is the one which converges with English structures of the type $\mathrm{N}$ and $\mathrm{N}$ (i.e. $\mathrm{N}$-ádí $\mathrm{N}$ ) as represented in (5) below.

(5) sen-ná-dí kwiyó-wá-dí

sen-ná-dí kwiyó the man and the woman sen kwiyó-wá-dí

There is also evidence that some discourse phenomena join grammar in their location outside the awareness of speakers. In comparative studies of Hopi, Arizona Tewa, and Rio Grande Tewa narratives, I found that though the Arizona Tewa evidential particle $b a$, as previously discussed in (1), was clearly related to a homologous one in Rio Grande Tewa, its pattern of usage more clearly resembled that of the Hopi quotative particle yaw (as in Arizona Tewa example (6) and Hopi (7).

(6) 'i-wae ba, di-powa-di ba, 'ó:bé-khwo:li-mak'a-kánt'ó-dí there-at ba, they-arrive-SUB ${ }^{7}$ they:INV-fly-teach-SUB

From there so, having arrived so, they were being taught to fly.

(7) noq yaw 'ora:yvi 'atka ki:tava yaw piw ticvo ki'yta

and yaw Oriabi below:south from:villabe yaw also wren she-live

And wren also lived below Oriabi, south of the village.

(from Seumptewa, Voegelin, and Voegelin 1980)

In both its frequent and multiple occurence within sentences as well as its general service as a genre-marker, the Arizona Tewa pattern of use appears to have converged with the Hopi and departed from the norms of other Tewa narrative traditions.

\section{Linguistic Indexing of Identity}

The final dimension of Tewa linguistic ideology concerns itself with the Tewa

${ }^{7}$ SUB is an abbreviated gloss for subordinator - a grammatical marker for dependent clauses. 
preference for locating the speaking self in a linguistically well- defined, possibly positional, socio-cultural identity and the belief that speech behavior, in general expresses important information about the speaker's identity. Related to this is a comment once made to me by Albert Yava, regarding the way attention to the speech of others is used to locate them in sociocultural space: "I only have to hear someone talk for a short while before I know who they are and where they have been."

In addition to this cultural idea that one's speech is a linguistic biography, the model of ritual speech foregrounds the importance of positional, rather than personal, identities and the use of appropriate role-specific speech.

Outside of kiva talk, we find similar emphases in the more mundane genres of traditional stories and public announcements. In stories, as mentioned above, the narrator establishes and maintains his status through adoption of the full range of narrative conventions including the use of evidential $b a$. These practices permit narrators to adopt the voice of the traditional storyteller in order to "speak the past". Similarly a conventional component of public announcements is the explicit acknowledgement by the chanter of his mediating status as spokesperson. The scope of this penchant for conveying identity through use of an associated code extends to casual conversation. Between trilingual Tewa men conversing in domestic settings it was not unusual to hear code-switching deployed for just such expressive purposes. Example 8 , extracted from a more detailed study of code-switching (Kroskrity in press) is a brief strip of talk in which a code-switch signals a reformulation of identity for the speaking selves.

(8)

F: [HOPI] Titiqaki-t qa-na:nawakna.

'Schools were not wanted'.

G: [TEWA] Wé-dí-t'ókán-k’ege-na'a-di im-bí akhon-i-di

'They didn't want a school on their land

H: [TEWA] Naembí e:yae nạeląe-mo díbí-t'o-'am-mí

ką:yji we-di-mu:di.

'It's better our children go to school right

here rather than far way'.

Three senior Tewa men have been discussing then recent news about the selection of an on-reservation site for the building of a high school. This topic follows from prior discussion of other building projects on the Reservation. As is customary in discussing extra-village reservation matters the conversation, in which all three men have contributed has been conducted in Hopi. Speaker F merely notes opposition to previous efforts to create an on-reservation high school. But speakers $\mathrm{G}$ and $\mathrm{H}$ switch to Tewa to reformulate their speaking selves as Tewa - members of a group who historically have opposed prior Hopi obstruction of building plans. G's use of Tewa further distances himself from the Hopi "they" who opposed use of "their" tribal lands as school sites. $\mathrm{H}$ states what has historically been the Arizona Tewa argument for a 
reservation high school. Since, in retrospect, most Hopi and Tewa individuals now recognize the disruptive impact on their children caused by their attending boarding schools for the past few decades, H's remark also evaluates the essential correctness of the position promoted by their ethnic group. In both G's and H's remarks the selection of the "marked" code given the topic reformulates their relevant interactional identity as Arizona Tewa. Thus the practice of maintaining maximally distinctive codes through strict compartmentalization provides the Tewa with appropriate linguistic resources in order to invoke a variety of corresponding sociocultural identities in interaction. Awareness (Silverstein 1981) of this aspect of language use on the part of Arizona Tewa speakers is expectably selective. Many speakers recognize the resources which their linguistic repertoires provide in permitting them to perform multiple social identities. These speakers often liken their languages and linguistic levels to masks and costumes worn for a specific ceremony.

But it is useful to note that although the Arizona Tewa openly acknowledge a close association between language and identity, as mentioned above, they do not recognize conversational code-switching as a locus for the expression of identity. This is, no doubt, tied to the fact that most Arizona Tewa trilinguals deny that they codeswitch even though they routinely engage in this practice. This denial may reflect not only the fact that these behaviors are largely taken-for-granted but also a popular confusion between culturally devalued "code- mixing" and codeswitching.

\section{Conclusions}

Considerations of space permit only some brief observations rather than extended conclusions. In this study I have only begun to explore the potentially fruitful application of the notion of language ideology to the Arizona Tewa speech community. I agree with Friedrich (1989: 309) who distinguishes several especially valuable senses of "ideology" and will employ two of these distinctions in my concluding remarks as a means of assessing what has been accomplished and what remains to be done.

Attending to the "notational" sense of ideology, as the basic notions or ideas that members have about a well-demarcated area of a culture, an attention to culturally dominant linguistic ideology greatly improves on the limited "etic" understanding provided by the notion of "linguistic conservatism". Linguistic ideology permits an account which captures the cultural unity of otherwise disparate linguistic norms and discourse practices and the guided agency of Tewa speakers in exercising their necessarily selective control over their linguistic resources. The Arizona Tewa were and continue to be an instructive example of how folk consciousness and rationalization of language structure and use can have a powerful effect on language contact outcomes.

The "pragmatic" sense of ideology - the strategies, practical symbols and systems of ideas used for promoting, perpetuating or changing a social or cultural order directs attention to the role of such local models of language structure and use as instruments of power and social control. It is important to remember that Pueblo ceremonial language, like ceremonial behavior in general, is not only the expression of 
religious belief through the sacred manipulation of cosmic forces but also the implicit justification of rule by a largely hereditary ceremonial elite. Thus linguistic ideology provides a socially motivated explanation for the social process and linguistic products which are merely labelled by the expression "linguistic conservatism". Clearly more work needs to be done in this area in order to relate linguistic ideologies to local political forces (e.g. Dozier 1966) and to recognize the existence of contending ideologies rather than representing the dominant one as if it were uniformly accepted.

Given the connections between ceremonial and more mundane speech delineated here, as well as the partial awareness of it reflected in the rejection of my early claims to diplomatic immunity through appeal to an "autonomous" language, it was no wonder that my early Tewa interrogators would find their language so valuable and linguistic research so controversial.

\section{References}

Annamalai, E. (1989) The linguistic and social dimensions of purism. In B. H. Jernudd and M. J. Shapiro (eds.), The politics of language purism, 225-31. Berlin: Mouton.

Black, R. (1967) Hopi grievance chants: A mechanism of social control. In D. Hymes \& W. Bittle (eds.), Studies in Southwestern ethnolinguistics, 54-67. The Hague: Mouton.

Dozier, E. P. (1956) Two examples of linguistic acculturation: The Yaqui of Sonora and the Tewa of New Mexico. Language 32:146-57.

Dozier, E.P. (1966) Factionalism at Santa Clara Pueblo. Ethnology 5:172-85.

Friedrich, P. (1989) Language, ideology, and political economy. American anthropologist 91:295-312.

Garfinkel, H. (1967) Studies in ethnomethodology. Englewood-Cliffs, New Jersey: Prentice-Hall.

Geertz, C. (1968) Islam observed: Religious developments in Morocco and Indonesia. Chicago: University of Chicago Press.

Giddens, A. (1984) The constitution of society. Berkeley: University of California Press.

Henningsen, M. (1989) The politics of purity and exclusion. In Jernudd \& Shapiro (eds.), The politics of language purism, 31-52. Berlin: Mouton.

Kalectaca, M. (1978) Lessons in Hopi. Tucson: University of Arizona Press.

Kroskrity, P.V. (1978) Aspects of syntactic and semantic variation in the Arizona Tewa speech community. Anthropological linguistics 20:235-258.

Kroskrity, P.V. (1982) Language contact and linguistic diffusion: the Arizona Tewa Speech Community. In F. Barkin et. al. (eds.), Bilingualism and language contact, 51-72. New York: Columbia Teachers College Press. 
Kroskrity, P.V. (1985a) "'Growing with stories': Line, verse, and genre in an Arizona Tewa text." Joumal of anthropological research 41:183-200.

Kroskrity, P.V. (1985b) Areal influences on Tewa possession. International joumal of American linguistics 51:486-9.

Kroskrity, P.V. (in press) Language, history, and identity: ethnolinguistic studies of the Arizona Tewa. Tucson: University of Arizona Press.

Kroskrity. P.V. and D. Healing (1978) Coyote and Bullsnake. In W. Bright (ed.), Coyote stories (IJAL Native American Texts Series, Monograph No. 1, 162-70). Ann Arbor: University Microfilms.

Newman, S. (1955) Vocabulary levels: Zuni sacred and slang usage. Southwestern journal of anthropology 11:345-54.

Schroeder, A.H. (1979) Pueblos abandoned in historic times. In A. Ortiz (ed.) Southwest (Volume 9 Handbook of North American Indians), 236-54).

Seumptewa, E., C.F. Voegelin and F.M. Voegelin (1980) Wren and Coyote (Hopi). In M.B.Kendall (ed.), Coyote stories II (IJAL Native American Texts Series, Monograph No. 6, 104-110. Ann Arbor: University Microfilms.

Sherzer, J. (1976) An areal-typological study of American Indian languages North of Mexico. Amsterdam: North-Holland.

Silverstein, M. (1979) Language structure and linguistic ideology. In P. Clyne et. al. (eds.), The elements: A parasession on linguistic units and levels, 193-247. Chicago Linguistics Society.

Sitverstein, M. (1981) The limits of awareness. Working papers in sociolinguistics, 84. Austin: Southwest Educational Development Library.

Sitverstein, M. (1985) Language and the culture of gender: At the intersection of structure, usage, and ideology. In E. Mertz \& R. Parmentier (eds.), Semiotic mediation, 219-239. Orlando, FL: Academic Press.

Simmons, M. (1979) History of Pueblo-Spanish relations to 1821. In A. Ortiz (ed.), Southwest (Volume 9 of the Handbook of North American Indians), 178-93. Washington: Smithsonian.

Yava, A. (1978) Big Falling Snow. New York: Crown. 